\title{
PENGARUH PELAYANAN TERHADAP PARTISIPASI ANGGOTA PADA KOPERASI SISWA DI SMP 8 MADIUN
}

\author{
Suci Rahmawati \\ Mahasiswa Prodi Pendidikan Ekonomi IKIP PGRI Madiun
}

\begin{abstract}
Abstrak: Tujuan dari penelitian ini adalah untuk mengetahui layanan yang diberikan oleh koperasi, untuk menentukan peningkatan partisipasi anggota dalam studentscooperative SMP 8 Madiun, serta untuk menentukan apakah atau tidak pengaruh pelayanan kepada anggota koperasi partisipasi SMP 8 Madiun . Sampel dalam penelitian ini menggunakan random sampling bahwa koperasi sebanyak 85 anggota. pengumpulan data menggunakan kuesioner. Dalam menganalisis data yang digunakan korelasi produk moment metode statistik untuk menguji apakah atau tidak instrumen valid dan metode yang digunakan untuk uji regresi meneliti hipotesis yang diajukan dalam penelitian ini. Hasil penelitian menunjukkan bahwa pelayanan memiliki hubungan dan pengaruh yang positif terhadap partisipasi anggota koperasi 8 siswa Madiun SMP. Hal ini diperoleh dari uji korelasi menunjukkan nilai 0,000 sedangkan besarnya Sighit Sigprob 0,05. Ini berarti bahwa nilai Sighit $\leq$ Sigprob $(0,000 \leq 0,05)$ berarti penolakan $\mathrm{H} 0$ yang menunjukkan bahwa partisipasi anggota memiliki hubungan kerjasama dengan layanan di 8 siswa Madison SMP. Selanjutnya juga besarnya hasil yang diperoleh adalah 0,000 sedangkan Sigprob Sighit 0,05. Ini berarti bahwa Sighit $\leq$ Sigprob $(0,000 \leq 0,05)$ berarti penolakan H0 yang menunjukkan bahwa ada layanan yang signifikan kepada anggota partisipasi koperasi SMP 8 Madiun. Juga memperoleh hasil uji t, nilai adalah 0,000 sedangkan Sighit Sigprob 0,05. Ini berarti bahwa nilai Sighit $\leq$ Sigprob $(0,000 \leq 0,05)$ berarti penolakan H0 yang menunjukkan bahwa ada efek yang berbeda pada partisipasi anggota koperasi layanan 8 siswa Madison SMP. Hasil R2 0,263 Hal ini menunjukkan bahwa 26,3\% jasa koperasi variabel dipengaruhi oleh partisipasi anggota koperasi sedangkan sisanya $73,7 \%$ dipengaruhi oleh faktor lain.
\end{abstract}

Keywords : layanan, partisipasi anggota

\section{PENDAHULUAN}

Dalam era yang modern sekarang ini banyak sekali masyarakat melupakan koperasi dan peran koperasi di desa maupun di kota. Padahal koperasi sangat penting bagi masyarakat untuk mengembangkan usahanya. Lewat koperasi atau meminjam uang di koperasi dengan bunga yang kecil, namun banyak orang yang tidak memperdulikannya. Sehingga masyarakat banyak yang memilih meminjam ke renternir yang bunganya lebih besar daripada meminjam uang ke koperasi yang bunganya lebih ringan, selain itu juga dalam koperasi kita bisa mendapatkan pelayanan yang memuaskan kita dalam berkoperasi.

Koperasi dikenal sebagai suatu bentuk perusahaan yang unik. Koperasi tidak hanya dianggap berbeda dari perusahaan perseorangan yang berbentuk $\mathrm{CV}$, tapi juga dianggap tidak sama dengan perusahaan yang dimiliki oleh sekumpulan orang seperti Firma dan Perseorangan Terbatas (PT). Koperasi dapat bersaing dengan organisasi-organisasi lain dalam hal anggota, modal, pelanggan, dan pelayanan dll. Namun meraka juga harus menawarkan kelebihan khusus yang tidak akan dapat diberikan oleh organisasi lainnya 
dan hanya dapat terrealisasi oleh individuindividu jika mereka menjadi anggota suatu koperasi. Menurut Hendar (2010,136) Koperasi adalah organisasi yang mempunyai ciri berbeda dengan organisasi lainnya, yaitu organisasi ekonomi yang di mana anggotanya sebagai pemilik sekaligus pelanggan utama perusahaan itu. Sedangkan Koperasi sekolah sebagai penunjang pendidikan sekolah ke arah kegiatan-kegiatan praktis, untuk mencapai kebutuhan ekonomi di kalangan siswa dan mengembangkan rasa tanggung jawab, disiplin, setia kawan, dan jiwa demokratis para siswa. Pengembangan koperasi sekolah sebagai organisasi yang bergerak di bidang ekonomi harus di kelola berdasarkan prinsip-prinsip manajemen. Supaya siswa mengerti cara mengelola koperasi, guru harus memberikan bimbingan dan pembinaan dalam pengurusan koperasi.

\section{KAJIAN PUSTAKA Pelayanan}

Menurut Kotler dalam Sampara Lukman (dalam Lijan Poltak Sinambela, 2006: 4-5) pelayanan adalah setiap kegiatan yang menguntungkan dalam suatu kumpulan atau kesatuan dan menawarkan kepuasan meskipun hasilnya tidak terikat pada suatu produk secara fisik. Sampara berpendapat (dalam Lijan Poltak Sinambela, 2006: 4-5) pelayanan adalah "suatu kegiatan atau urutan kegiatan yang terjadi dalam interaksi langsung antar seseorang dengan orang lain atau mesin secara fisik dan menyediakan kepuasan pelanggan.

Faktor-faktor yang mendukung pelayanan umum adalah:

1) Faktor kesadaran

Kesadaran menunjukkan suatu keadaan pada jiwa seseorang yaitu merupakan titik temu dari berbagi pertimbangan sehingga diperoleh suatu keyakinan, ketenangan, ketetapan hati dan keseimbangan jiwa yang bersangkutan. Proses tumbuhnya kesadaran berbeda pada setiap orang baik dalam hal kecepatan maupun dalam hal kualitas pelayanan.

2) Faktor aturan

Makin maju dan majemuk suatu masyarakat makin besar peranan aturan yang dapat dikatakan tidak dapat hidup layak dan tenang tanpa aturan. Oleh karena itu peranan aturan demikian besar dalam hidup bermasyarakat maka dengan sendirinya aturan harus dibuat dan dipatuhi dan diawasi sehingga dapat mencapai sasaran sesuai yang dimaksud.

3) Faktor organisasi

Organisasi pelayanan tidak ada bedanya dengan pelayanan pada umumnya, namun ada perbedaan sedikit dalam penerapannya, karena sasaran pelayanan ditujukan secara khusus kepada manusia yang mempunyai watak.

4) Faktor pendapatan

Pada dasarnya pendapatan harus dapat memenuhi kebutuhan koperasi baik untuk pengurus ataupun yang menjadi anggota koperasi. Kebutuhan hidup yang semakin meningkat di satu pihak, kurang dapat diimbangi dengan pendapatan yang relatif tetap.

5) Faktor kemampuan ketrampilan.

Kemampuan merupakan menunjukkan sifat atau keadaan seseorang yang dapat melaksanakan tugas atau pekerjaan atas dasar ketentuan-ketentuan yang ada. Sedangkan keterampilan ialah kemampuan melaksanakan tugas dengan menggunakan anggota badan dan peralatan kerja yang tersedia. Dengan begitu keterampilan lebih banyak mengunakn unsur anggota badan daripada unsur yang lainnya.

6) Faktor sarana pelayanan.

Sarana pelayanan yang dimaksud disini ialah segala jenus peralatan, perlengkapan kerja dan fasilitas yang lainnya yang berfungsi sebagai alat utama atau pembantu dalam melaksanakan pekerjaan dan juga berfungsi sosial dalam rangka kepentingan orang-orang yang sedang berhubungan dengan organisasi lain. 


\section{Partisipasi Anggota}

Partisipasi memegang peran yang menentukan dalam perkembangan koperasi. Tanpa partisipasi anggota, koperasi tidak akan bekerja dengan efisien dan efektif. Suatu koperasi bisa berhasil dalam kompetisi, tetapi tak akan ada artinya bila anggota tak memanfaatkan keungulan yang dimiliki tersebut.

Hendar (2010: 167) menyatakan bahwa partisipasi adalah kondisi yang diperlukan untuk penampilan komparatif yaitu agar pihak manajemen koperasi tahu apa yang menjadi kepentingan anggotanya dan berapa banyak serta kualitas pelayanan yang diperlukan oleh para anggotanya.

Menurut Hendar (2010: 168) partisipasi dimaknai sebagai keikutsertaan anggota dalam kegiatan kegiatan tertentu, baik dalam kondisi yang menyenangkan ataupun dalam kondisi yang tidak menyenagkan.

Menurut Alfred Hanel (2005:78-79) dimensi-dimensi partisipasi itu saling berkaitan sebagai berikut :

a. Para anggota perorangan akan berpartisipasi dalam kegiatan pelayanan suatu perusahaan koperasi yang secara efisien menunjang kepentingannya.

b. Para anggota harus mneyetujui dan harus digerakkan melalui ketentuan-ketentuan organisasi, untuk berperan serta dalam membiayai perusahaan koperasi yang cukup dan struktur orgaisasi yang sesuai serta manajemen yang profesional, termotivasi dan dinamis sehingga mampu memnciptakan potensi yang diperlukan untuk menunjang kegiatan para anggotanya secara efisien sesuai dengan kebutuhan kepentingan dan tujuannya.

c. Hal itu berarti bahwa para anggota memiliki hak dan kesempatan serta termotivasi, dan sanggup berpartisipasi dalam mengambil keputusan mengenai tujuan yang hendak dicapai dan dalam mengendalikan/mengawasi prestasi organisasi koperasi dan perushaan koperasinya.

\section{Koperasi dan Koperasi Sekolah}

Menurut Sonny Sumarsono (2003:1) koperasi adalah suatu perkumpulan yang beranggotakan orang-orang atau badanbadan hukum koperasi yang memberikan kebebasan masuk dan keluar sebagai anggota dengan bekerjasama secara kekeluargaan menjalankan usaha untuk mempertinggi kesejahteraan para anggotanya.

Sedangkan Hendar (2010:136) koperasi adalah organisasi dengan ciri yang berbeda dengan organisasi lainnya, yaitu organisasi ekonomi dimana anggotanya sebagai pemilik sekaliggus pelanggan utama perusahaan itu. Koperasi adalah organisasi yang mempunyai tujuan meningkatkan kesejahteraan anggotanya.

Sedangkan koperasi sekolah adalah koperasi yang berada dalam lingkungan sekolah yang anggotanya adalah siswa dari sekolah tersebut yang dapat melakukan kegiatan ekonomi tanpa badan hukum. Struktur organisasi koperasi siswa yaitu tersusun atas dewan penasihat dan alat perlengkapan organisasi. Dewan penasihat terdiri atas kepala sekolah, guru dan perwakilan orang tua siswa. Sedangkan alat perlengkapan organisasi terdiri dari rapat anggota, pengurus koperasi dan badan pemeriksa / pengawas.

\section{Tujuan Koperasi dan Koperasi Sekolah}

Sony Sumarsono (2003: 6) menyatakan tujuan utama pendirian suatu koperasi adalah untuk meningkatkan kesejahteraan ekonomi para anggotanya. Namun demikian, karena dalam memperjuangkan peningkatan kesejahteraan ekonomi anggotanya itu koperasi berpegang pada asas dan prinsipprinsip ideal tertentu, maka kegiatan koperasi biasanya juga diharapkan dapat membantu meningkatkan kesejahteraan masyarakat secara keseluruhan. Sedangkan Sedangkan tujuan koperasi sekolah adalah untuk menunjang pendidikan siswa dan melatih para siswa untuk berkoperasi. Dengan demikian, tujuannya tidak lepas dari pendidikan 
dan program pemerintah dalam menanamkan kesadaran berkoperasi sejak dini.

Partisipasi memegang peran penting bagi koperasi karena koperasi harus meningkatkan pelayanannya terhadap anggota supaya anggota dapat berpartisipasi di koperasi denagn sukarela. Jika koperasi mampu memberikan pelayanan yang maksimal atau sesuai dengan kebutuhan yang dibutuhkan oleh anggota maka tingkat partisipasinya akan meningkat. Aagr dapat meningkatkan pelayanan koperasi membutuhkan infomasi-inforamsi yang datang dari anggotanya. Sehinga para anggota dapat mempengaruhi dan mengendalikan manajemen tidak hanya memberikan kritik dan saran dalam meningkatkan pelayanan yang diberikan tetapi dapat memberhentikan pihak manajemen dan fungsi yang didudukinya.

\section{METODE PENELITIAN}

Tempat untuk penelitian yaitu koperasi siswa SMP 8 Madiun jl. Pilang mulya no 20 Madiun. Rancangan yang digunakan dalam penenlitian ini adalah penelitian deskritif. Deskriptif adalah untuk menggambarkan/ memecahkan masalah secara sistematis, faktual,dan akurat mengenai fakta-fakta dan sifat-sifat populasi atau daerah tertentu.

Rancangan penelitian dapat dilihat pada gambar sebagai berikut:

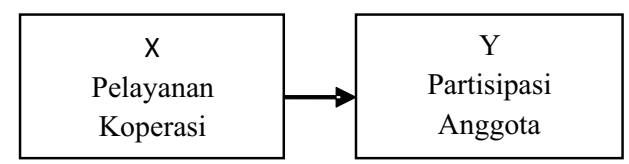

\section{Gambar Rancangan Penelitian}

Dalam penelitian ini variabel bebas $(\mathrm{X})$ adalah pelayanan dan variabel terikat $(\mathrm{Y})$ adalah partisipasi anggota. Dalam penelitian ini yang menjadi populasi adalah 85 siswa. Teknik pengumpulan data yang digunakan dalam penelitian ini adalah teknik angket. Jumlah soal dalam kuesioner ini adalah 25 butir soal yang dibagi dalam 2 variabel dengan perincian 15 soal untuk variabel pelayanan dan 10 soal untuk variabel partisipasi anggota.

\section{HASIL PENELITIAN \\ Variabel Pelayanan}

Deskripsi data variabel pelayanan dengan data $\mathrm{N}$ sebanyak 85 dengan deskripsi data sebagai berikut : adalah sebagai berikut: (a) jumlah total skor sebesar 4896; (b) mean 57.60; (c) median 59.00; (d) mode 61; (e) standar deviasi 6.381; (f) minimum 39; (g) maximum 73. Dari hasil analisis deskriptif dengan jumlah 85 siswa yang mendapat nilai diatas mean $(>57)$ sebanyak 55 siswa atau $64,7 \%$ hal ini dapat dikatakan baik. Sedangkan yang mendapat nilai di bawah rata-rata sebanyak 30 siswa atau $35,2 \%$ dapat dikatakan kurang baik.

\section{Variabel Partisipasi Anggota}

Variabel partisipasi anggota koperasi dengan jumlah N 85 siswa yang diketahui data statistik deskriptifnya adalah sebagai berikut: (a) jumlah total skor sebesar 3147.00; (b) mean 37.0235; (c) median 37.0000; (d) mode 42.00; (e) standar deviasi 6.10421; (f) minimum 24.00; (g) maximum 49.00. Dari hasil analisis deskriptif dengan jumlah 85 siswa yang mendapatkan nilai diatas mean (>37) sebanyak 40 siswa atau $47 \%$ dapat dikatakan cukup baik. Sedangkan yang mendapat nilai dibawah rata-rata sebanyak 45 siswa atau 52,9\% dapat dikatakan baik.

\section{Hasil Uji Korelasi}

Hasil uji korelasi besarnya nilai $r_{\text {hitung }}$ sebesar 0,513 sedangkan $r_{\text {tabel }}$ 0,213 .Dilain pihak nilai $\mathrm{Sig}_{\text {hitung }}$ sebesar 0,000 dan $\mathrm{Sig}_{\text {prob }}$ sebesar 0,05 . Hal ini $r_{\text {hitung }} \geq r_{\text {tabel }}(0,513 \geq 0,213)$ atau $\operatorname{Sig}_{\text {hit }} \leq \operatorname{Sig}_{\text {prob }}(0,000<0,05)$. dapat diartikan bahwa ada hubungan antara pelayanan koperasi terhadap partisipasi anggota koperasi pada koperasi siswa SMP 8 madiun. Lebih lanjut diperoleh pada nilai $\mathrm{R}^{2}$. Nilai $\mathrm{R}^{2}$ sebesar 0,263 hal ini dapat diartikan bahwa sebesar $26,3 \%$ variabel pelayanan 
koperasi dipengaruhi oleh partisipasi anggota koperasi sedangkan sisanya $73,7 \%$ dipengaruhi oleh faktor lain.

\section{Uji Fisher}

Hasil dari uji fisher sebesar nilai $\mathrm{F}_{\text {hitung }}$ 29,610sedangkan $F_{\text {tabel }}$ 3,956.Di lain pihak nilai Sig $_{\text {hitung }}$ sebesar 0,000 dan Sig $_{\text {prob }} 0,05$ berarti $F_{\text {hitung }} \geq F_{\text {tabel }}(29,610 \geq 3,956)$ dan $\operatorname{Sig}_{\text {hit }} \leq \operatorname{Sig}_{\text {prob }}(0,000 \leq 0,05)$, hal ini dapat dikatakan $\mathrm{H}_{0} \mathrm{~d}_{\mathrm{i}}$ tolak, ada pengaruh secara keseluruhan antara pelayanan koperasi terhadap partisipasi anggota.

\section{Uji t}

Hasil analisis di atas disusun persamaan regresi sebagai berikut: $Y=8.769+0,491 \mathrm{X}$. Sehingga dapat dikatakan jika pelayanan mengalami kenaikan 1\% akan memberikan kenaikan nilai partisipasi anggota $0,491 \%$ sedangkan faktor lain dianggap tetap. Oleh sebab itu dalam persamaan koefisien regresi dapat diperoleh nilai $t_{\text {hitung }}$ sebesar $5,442 \mathrm{t}_{\text {tabel }}$ sebesar 0,846. Dilain pihak nilai $\operatorname{Sig}_{\text {hit }}$ sebesar 0,000 dan $\mathrm{Sig}_{\text {prob }}$ sebesar 0,05 hal ini berarti bahwa $\operatorname{Sig}_{\text {hit }} \leq \operatorname{Sig}_{\text {prob }}$ ataut $_{\text {hitung }} \geq t_{\text {tabel }}(5,442 \geq$ $0,846$ atau $0,000 \leq 0,05)$ ini dapat dikatakan $\mathrm{H}_{0}$ ditolak, terdapat beda pengaruh antara pelayanan terhadap partisipasi anggota pada koperasi siswa SMP 8 Madiun.

\section{Simpulan Hasil Analisis}

Atas dasar analisis di atas hasil analisi dapat diambil kesimpulan sebagai berikut :

\section{Simpulan Uji Korelasi}

Dari hasil pengujian analisis korelsi dapat diperoleh besanya nilai $r_{\text {hitung }}$ sebesar 0,513 sedangkan $r_{\text {tabel }} 0,213$. Di lain pihak nilai $\mathrm{Sig}_{\text {hitung }}$ sebesar 0,000 dan $\mathrm{Sig}_{\text {prob }}$ sebesar 0,05. Hal ini $r_{\text {hitung }} \geq r_{\text {tabel }}(0,513 \geq 0,213)$ atau $\operatorname{Sig}_{\text {hit }} \leq$ $\operatorname{Sig}_{\text {prob }}(0,000<0,05)$. Nilai $\mathrm{R}^{2}$ sebesar 0,263 hal ini dapat diartikan bahwa sebesar 26,3\% variabel pelayanan koperasi dipengaruhi oleh partisipasi anggota koperasi sedangkan sisanya $73,7 \%$ dipengaruhi oleh faktor lain.

Dapat disimpulkan bahwa $\mathrm{H}_{0}$ ditolak yang berarti ada hubungan pelayanan dengan partisipasi anggota pada koperasi siswa SMP 8 Madiun.

\section{Simpulan Uji Fisher}

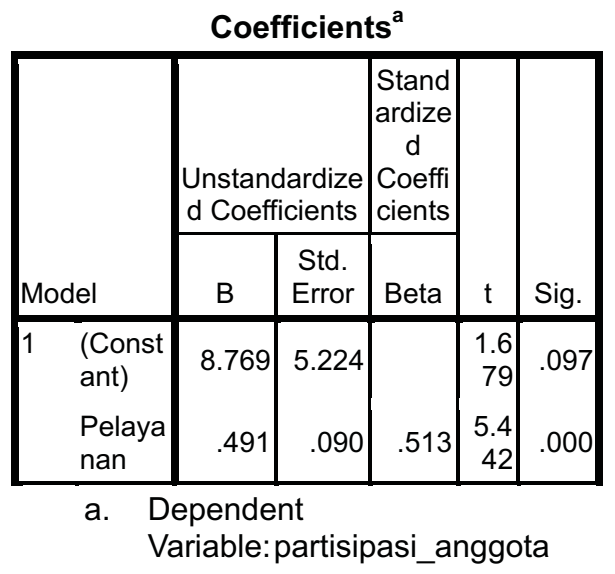

Berdasarkan perhitungan yang telah dilakukan dengan uji $F$ diketahui $F_{\text {hitung }}$ $(29,610) \geq F_{\text {tabel }}(3,956)$ atau $\operatorname{Sig}_{\text {hit }}$ sebesar $0,000 \leq \operatorname{Sig}_{\text {prob }}$ 0,05. Dapat disimpulkan bahwa $\mathrm{H}_{0}$ ditolak yang berarti ada pengaruh pelayanan terhadap partisipasi anggota pada koperasi siswa SMP 8 Madiun.

\section{Simpulan Uji t}

Berdasarkan hasil analisisi dapat disususn perumusan regresi sebagai berikut: $\mathrm{Y}=8.769+0,491 \mathrm{X}$. dalam persamaan koefisien regresi, diperoleh nilai $\mathrm{t}_{\text {hitung }}$ sebesar 5,442 sedangkan $t_{\text {tabel }}$ sebesar 0,846 Dilain pihak nilai $\mathrm{Sig}_{\text {hit }}$ sebesar 0,000 dan $\mathrm{Sig}_{\text {prob }}$ sebesar 0,05. Hal ini berarti bahwa $\mathrm{Sig}_{\text {hit }}$ $\leq \operatorname{Sig}_{\text {prob }}$ ataut $_{\text {hitung }} \geq \mathrm{t}_{\text {tabel }}(5,442 \geq 0,846$ atau $0,000 \leq 0,05)$ Hal ini dapat disimpulkan bahwa $\mathrm{H}_{0}$ ditolak, artinya terdapat beda pengaruh antara pelayanan terhadap partisipasi anggota pada koperasi siswa SMP 8 Madiun.

\section{PEMBAHASAN}

Hasil penelitian menunjukkan bahwa pelayanan berpengaruh terhadap partisipasi anggota. Selain itu Pelayanan pada umumnya ditujukan melalui sikap mereka untuk para 
anggotanya, disaat para anggotanya puas dengan pelayanan sehingga para anggota akan datang lagi di koperasi untuk berbelanja.

Selanjutnya adalah pembahasan untuk uji regresi yang meliputi uji korelasi, uji Fisher, dan uji t.

\section{Pembahasan Uji Korelasi}

Uji korelasi besarnya nilai $r_{\text {hitung }}$ sebesar 0,513 sedangkan $r_{\text {tabel }} 0,213$. Dilain pihak nilai Sig $_{\text {hitung }}$ sebesar 0,000 dan $\mathrm{Sig}_{\text {prob }}$ sebesar 0,05. Hal ini $r_{\text {hitung }} \geq r_{\text {tabel }}(0,513 \geq 0,213)$ atau $\operatorname{Sig}_{\text {hit }} \leq$ $\operatorname{Sig}_{\text {prob }}(0,000<0,05)$. Berarti $\mathrm{H}_{0}$ ditolak yang berarti ada hubungan pelayanan dengan partisipasi anggota pada koperasi siswa SMP 8 madiun. Nilai $\mathrm{R}^{2}$ sebesar 0,263 hal ini dapat diartikan bahwa sebesar $26,3 \%$ variabel pelayanan koperasi dipengaruhi oleh partisipasi anggota koperasi sedangkan sisanya $73,7 \%$ dipengaruhi oleh faktor lain.

\section{Pembahasan Uji Fisher}

Uji $\mathrm{F}$ dalam penelitian ini diperoleh hasil yaitu $F_{\text {hitung }}(29,610)>F_{\text {tabel }}(3,956)$ atau $\operatorname{Sig}_{\text {hit }}$ sebesar 0,000 $<\operatorname{Sig}_{\text {prob }}$ 0,05 dalam hal ini berarti $\mathrm{H}_{0}$ ditolak, ada pengaruh secara keseluruhan antara pelayanan terhadap partsisipasi anggota pada koperasi siswa SMP 8 Madiun.

\section{Pembahasan Ujit}

Berdasarkan hasil analisis dapat disusun persamaan sebagai berikut: $\mathrm{Y}=8,769$ + 0491X, yang berarti jika pelayanan mengalami kenaikan 1\%, akan memberikan kenaikan nilai partisipasi anggota sebesar $0,491 \%$ sedangkan sisanya faktor lain dianggap tetap.

Oleh sebab itu dalam persamaan koefisien regresi, diperoleh nilai $t_{\text {hitung }}$ sebesar 5,442 sedangkan $t_{\text {tabel }}$ sebesar 0,846 Di lain pihak nilai $\mathrm{Sig}_{\text {hit }}$ sebesar 0,000 dan $\mathrm{Sig}_{\text {prob }}$ sebesar 0,05 . Hal ini dapat dikatakan bahwa $\mathrm{H}_{0}$ ditolak, artinya terdapat beda pengaruh antara pelayanan terhadap partisipasi anggota pada koperasi siswa SMP 8 Madiun.
Dari hasil penelitian dapat diartiakn bahwa pelayanan mempunyai hubungan sekaligus pengaruh terhadap partisipasi anggota. Sehingga pelayanan yang harus di berikan kepada anggota akan meningkatkan partisipasi anggotanya.

\section{PENUTUP \\ Simpulan}

Dari hasil penelitian dengan perolehan nilai kolerasi nilai $\operatorname{Sig}_{\text {hit }} \leq \operatorname{Sig}_{\text {prob }}(0,000 \leq 0,05)$ atau $r_{\text {hitung }} \geq r_{\text {tabel }}(0,513 \geq 0,213)$, untuk uji Fisher diperoleh nilai nilai $\operatorname{Sig}{ }_{\text {hit }} \leq \operatorname{Sig}_{\text {prob }}(0,000$ $\leq 0,05)$ atau $F_{\text {hitung }} \geq F_{\text {tabel }}(29,610 \geq 3,956)$, dan uji $\mathrm{t}$ diperoleh nilai $\operatorname{Sig}_{\text {hit }} \leq \operatorname{Sig}_{\text {prob }}(0,000$ $\leq 0,05)$ atau $t_{\text {hitung }} \geq t_{\text {tabel }}(5,442 \geq 0,846)$. Diperoleh pada nilai $\mathrm{R}^{2}$ sebesar 0,263 hal ini dapat diartikan bahwa sebesar $26,3 \%$ variabel pelayanan koperasi dipengaruhi oleh partisipasi anggota koperasi sedangkan sisanya $73,7 \%$ dipengaruhi oleh faktor lain. Dari semua uji di atas dapat disimpulkan bahwa $\mathrm{H}_{\mathrm{O}}$ ditolak, artinya dalam pelayanan koperasi di SMP 8 Madiun mempunyai pengaruh terhadap partisipasi anggota.

\section{Saran}

\section{Bagi Anggota}

Perlunya upaya untuk meningkatkan kesadaran kepada anggota koperasi untuk berpartisipasi dalam koperasi untuk meningkatkan layanan yang diberikan koperasi kepada anggota.

\section{Bagi Pengurus}

Pengurus harus lebih aktif lagi untuk meningkatkan pelayanan dikoperasi secara maksimal agar para anggota lebih aktif dalam berkoperasi dan bertransaksi di koperasi.

\section{Bagi Koperasi}

Pelayanan sangat besar pengaruhnya terhadap partisipasi anggota koperasi. Dengan pelayanan yang baik partisipasi anggota koperasi akan menjadi lebih baik dan menimbulkan keakraban anggota kepada 
pengurus, sehingga pelayanan selalu diberikan kepada anggota koperasi, agar benarbenar memberikan dampak yang baik bagi anggota itu sendiri maupun koperasinya.

\section{Bagi Penelitian Mendatang}

Bagi peneliti yang akan datang sebaiknya dapat mengembangkan atau mencari variabel lain, selain pelayanan karena masih banyak faktor lain yang harus diteliti yang dapat mempengaruhi partisipasi anggota koperasi.

\section{DAFTAR PUSTAKA}

Achmad Zanbar Saleh. 2005. Ilmu Statistik Pendekatan Teoritis dan Aplikasi disertai Penggunaan SPSS. Bandung: Rekayasa Sains Bandung.

Dwi Priyatno. 2010. Teknik Mudah dan Cepat Melakukan Analisis Data Penelitian dengan SPSS dan Tanya Jawab Ujian Pendadaran. Yogyakarta: Gava Media.

Hanel Alfred. 2005. Organisasi Koperasi. Yogyakarta: PT. Graha Ilmu.

Husein Umar. 2011. Metode Penelitian untuk Skripsi dan Tesis Bisnis. Jakarta: PT. Raja Grafindo Persada

Iqbal Hasan. 2004. Analisis Data Penelitian dengan Statistik. Jakarta: PT. Bumi Aksara.

Iskandar Soesilo. 2008. Dinamika Gerakan Koperasi Indonesia. Jakarta Selatan: RMBOOKS

Juliansyah Noor. 2011. Metodologi Penelitian Skripsi, Tesisi, Desertasi, dan Karya Ilmiah. Jakarta: Kencana.
Lijan Poltak Sinambela. 2006. Reformasi Pelayanan Publik. Jakarta: PT Bumi Aksara.

Mohaer Daniel. 2003. Metode Penelitian Sosial Ekonomi Dilengkapi Beberapa Alat Analisis dan Penentuan Penggunaan. Jakarta : PT. Bumi Aksara.

Moenir. 2006. Manajemen Pelayanan Umum Di Indonesia. Jakarta: PT Bumi Aksara.

Nanang Martono. 2010. Metode Penelitian Kuantitatif Analisis Isi dan Analisis Data Sekunder. Jakarta: PT. Raja Grafindo Persada.

Ninik Widiyanti dan Sunindhia. 2003. Koperasi dan Perekonomian Indonesia. Jakarta: PT. Rineka Cipta dan PT. Bina Adiaaksara.

Sony Sumarsono. 2003. Manajemen Koperasi. Yogyakarta: Graha Ilmu.

Sudarmiani. 2009. Akuntansi Koperasi Teori dan Praktek. Unesa University Press.

Sudarsono. 2010. Manajemen Koperasi Indonesia.Jakarta: PT. Rineka Cipta

Suharsimi Arikuntoi. 2002. Prosedur Penelitian. Jakarta. PT. Rineka Cipta

Sugiono. 2006. Metode Penelitian Kuantitatif Kualitatif dan $R \& D$. Bandung: CV. Alfabeta

Suharsimi Arikunto. 2010. Prosedur Penelitian Suatu Pendekatan Praktik. Jakarta: PT. Rineka Cipta.

Usman Rianse dan Abdi. 2012. Metodologi Penelitian Sosial dan Ekonomi Teori dan Aplikasi. Bandung: CV.Alfabeta. 